\title{
Morphological variation of Platanthera chlorantha (Orchidaceae) in forest sites of NW Poland
}

\author{
HELENA WiĘCŁAW, ${ }^{1}$ BARTOSZ KURNICKI ${ }^{2}$
}

\begin{abstract}
Department of Plant Taxonomy and Phytogeography, Institute for Research on Biodiversity, Faculty of Biology, University of Szczecin, Wąska 13, 71-415 Szczecin, e-mail: wieclawh@univ.szczecin.pl

2 Department of Botany and Nature Protection, Faculty of Biology, University of Szczecin, Felczaka 3a, 71-415 Szczecin
\end{abstract}

\begin{abstract}
Keywords morphology, labellum and spur variability, PCA, Dobrzany and Karnieszewice Forestries
Abstract The aim of this study was to check a hypothesis on the morphological variability of the Platanthera chlorantha growing in forests in the north-west of Poland (Dobrzany and Karnieszewice Forestries). Statistical techniques were used to analyse 16 morphological characters determined in 174 flowering specimens. A special attention was paid to the size of the spur and labellum. The following morphological characters showed statistically significant differences: spur, labellum, ovary, bract, lateral sepal, leaves and height of the specimens. The differences are most likely a result of different habitat conditions and the location of the study sites.
\end{abstract}

\section{Zmienność morfologiczna Platanthera chlorantha (Orchidaceae) w lasach północno- -zachodniej Polski}

Słowa kluczowe morfologia, zmienność warżki i ostrogi, PCA, Nadleśnictwo Dobrzany i Karnieszewice

Streszczenie Badania terenowe przeprowadzono w latach 2011-2012 na obszarze Nadleśnictwa Dobrzany i Karnieszewice (NW Poland). Celem badań było sprawdzenie hipotezy o zmienności morfologicznej podkolana zielonawego (Platanthera chlorantha). Zmierzono 174 okazy i statystycznie przeanalizowano 16 cech morfologicznych; szczególną uwagę zwrócono na wielkość warżki i ostrogi. Na podstawie przeprowadzonych analiz stwierdzono, że 1) zmienność cech morfologicznych badanych okazów prezentuje poziom niski; 2) cechy morfologiczne, takie jak: wielkość warżki, ostrogi, zalążni, przysadek, płatków bocznych i liści oraz wysokość roślin statystycznie istotnie różnią okazy z badanych stanowiskach; 3) nie ma wyraźnych różnic między wielkością warżki i ostrogi u okazów rosnących w cieniu i w miejscach słonecznych.

\section{Introduction}

The range of Platanthera chlorantha (Custer) Rchb. covers Europe (up to St. Petersburg area in the north), the Caucasus, Asia Minor and North Africa (Hultén, Fries 1986). In Poland, the species is rarer than P. bifolia (L.) Rich. and occurs at scattered sites throughout the country (Zając, Zając 2001). According to Zarzycki et al. (2002), the recent decades have witnessed 
a reduction of the species' sites in Poland and a significant decline in the number of individuals at the inhabited sites. In Western Pomerania, the species belongs to a group experiencing imminent danger of extinction in category E (Żukowski, Jackowiak 1995). The species has been granted a legal protection in Poland territory and it is covered by a partial species protection (Regulation of the Minister of Environment, 9 October 2014, Item 1409).

The aim of this study was to check a hypothesis on the morphological variability of the P. chlorantha growing in forests of the north-west of Poland (Dobrzany and Karnieszewice Forestries). These localities of $P$. chlorantha occurrence have not been included in the atlas of the vascular plant distribution in Poland (Zając, Zając 2001). The plant has been found growing in those localities thanks to the assistance of both forest districts' staff.

\section{Material and methods}

\section{Study species}

Platanthera chlorantha is mostly a component of meso- and eutrophic communities of deciduous forests representing the order Fagetalia sylvaticae. In some exceptional cases, it is encountered in the mixed Querco roboris-Pinetum forest, and on damp meadows of the order Molinietalia (Szlachetko 2001).

The species shows variation in the number, shape and size of leaves, in the size of the labellum and spur, and in the length and colour of the sepals (e.g. Szlachetko 2001). It hybridises with P. bifolia (e.g. Nilsson 1983; 1985; Claessens, Kleynen 2006; Bateman, Sexton 2008). The dimensions of the spur, a component playing a key role in attracting specific pollinators, has been in the focus of great attention of botanists, both traditional and evolutionary (e.g. Nilsson 1978; Bateman, Rudall 2006; Bateman, Sexton 2008; Bateman et al. 2009).

\section{Study area}

The fieldwork was carried out in June/July 2011 and July 2012 in the Dobrzany and Karnieszewice Forestries (NW Poland). Three research fields have been designated, two in the Dobrzany Forestry and one in the Karnieszewice Forestry.

Site 1 (Dobrzany Forestry, forest section 589a) features Quercus robur L., planted there about 10 years before; previously, the area had been planted with Populus sp. (W. Borzęcki, pers. comm.) and shows a mass occurrence of P. chlorantha. The trees grow to the maximum height of 2.5(3) m. Platanthera chlorantha grows abundantly in sunny spots between rows of the planted oak, and less abundantly directly in the shadow of oak canopies. The undergrowth yielded 37 vascular plant species, including meadow taxa of the class Molinio-Arrhenatheretea (e.g. Deschampsia caespitosa (L.) P. Beauv., Holcus lanatus L., Lathyrus pratensis L., Vicia cracca L.), fringe plants of the order Glechometalia hederaceae (e.g. Galium aparine L., Impatiens parviflora DC., Veronica chamaedrys L.), clearing species representing the class Epilobietea angustifolii (e.g. Calamagrostis epigejos (L.) Roth, Rubus idaeus L.) and, less abundant, forest taxa of the class Querco-Fagetea (e.g. Anemone nemorosa L., Aegopodium podagraria L., Dryopteris filix-mas (L.) Schott). A substantial contribution of meadow, clearing, and shrub species confirms a recent foresters' intervention in the area. Fortunately, the human intervention has not adversely affected the presence of $P$. chlorantha which continues to blossom and bear fruit at the site. 
Site 2 (Dobrzany Forestry, forest section 560g). At this site $P$. chlorantha is less abundant and grows in looser stands, compared to site 1. The trees are dominated by the beech (Fagus sylvatica L.) interspersed by the sparse European ash (Fraxinus excelsior L.). The trees grow to the height of $30 \mathrm{~m}$. The herb layer features 30 vascular plant species, mostly forest plants representative of the class Querco-Fagetea and the order Fagetalia sylvaticae (e.g. Carex sylvatica Huds., Galium odoratum (L.) Scop., Galeobdolon luteum Huds., Milium effusum L., Poa nemoralis L., Stachys sylvatica L.). The site is more shadowed and wetter than site 1.

Site 3 (Karnieszewice Forestry). In the Karnieszewice Forestry woods, P. chlorantha grows in widely scattered stands, usually a few specimens each, in numerous forest sections belonging to the Iwięcino, Mścice, and Koszalin Forestry Divisions. The species has been most often found in beech woods, growing together with herbaceous plants representing the order Fagetalia sylvaticae (e.g. Carex sylvatica, Galium odoratum, Galeobdolon luteum, Milium effusum, Polygonatum multiflorum (L.) All., Ranunculus lanuginosus L., Sanicula europaea L.) and was more seldom recorded on the outskirts of woodlands, accompanied by fringe species of the order Glechometalia hederaceae (e.g. Chaerophyllum temulum L., Galium aparine, Geranium robertianum L., Lapsana communis L.). It was also sporadically encountered in oak (Quercus robur) plantations, together with, i.a., Corylus avellana L., Galium aparine, Oxalis acetosella L., Populus tremula L. and Stellaria holostea L. Notwithstanding the scatter of the species' stands in the Karnieszewice Forestry, all the specimens measured were combined into a single group representing site 3 . The $P$. chlorantha specimens were found growing under different habitat conditions (different moisture and shadowing).

\section{Statistical analyses}

A total of 174 flowering specimens of $P$. chlorantha were studied in the field and 16 morphological characters were determined (Tab. 1). One flower located in the middle part of a fully developed inflorescence was measured without removing the flower. Flowers from the central part of the inflorescence are regarded as the least variable, and are most often used in biometric studies (Bateman, Rudall 2006). Measurements were taken with a ruler, to $0.1 \mathrm{~cm}$ (height and length of inflorescence, leaf size) and with a caliper, to $0.02 \mathrm{~mm}$ (size of flower components). In addition, detailed lists of vascular plants growing in P. chlorantha habitats were made.

The measurement data were processed statistically using Statistica ver. 10.0 for Windows. Significance of differences between the empirical distribution and the theoretical normal distribution was examined using the Shapiro-Wilk test. Since most of the data were non-normally distributed (Shapiro-Wilk's test), the non-parametric Kruskal-Wallis test and Dunn's multiple comparisons test were used to examine whether differences between taxa were significant. Basic statistical metrics (arithmetic mean, range - minimum and maximum values, standard deviation, and coefficient of variation) were determined for each morphological character. Relationships between morphological traits were assessed using Spearman's correlation coefficient.

All data (174 individuals and 16 morphological traits) were treated by the correlation matrixbased principal component analysis (PCA). The data to be used in multivariate analyses were standardized so that the arithmetic mean and standard deviation for each variable were 0 and 1 , respectively.

The nomenclature of vascular plants follows Mirek et al. (2002), while names of syntaxa are given after Matuszkiewicz (2005). 
Table 1. Morphological characters used for statistical analyses.

\begin{tabular}{|l|l|l|}
\hline No. & \multicolumn{1}{|c|}{ Characters } & \multicolumn{1}{|c|}{ Abbr. } \\
\hline 1. & plant height & H \\
\hline 2. & leaf length & LFL \\
\hline 3. & leaf width & LFW \\
\hline 4. & inflorescence length & IL \\
\hline 5. & number of flowers & NF \\
\hline 6. & labellum length & LL \\
\hline 7. & labellum width & LW \\
\hline 8. & spur length & SL \\
\hline 9. & $\begin{array}{l}\text { spur width, measured } \\
\text { at the final part }\end{array}$ & SW1 \\
\hline 10. & $\begin{array}{l}\text { spur width, measured } \\
\text { in the middle part }\end{array}$ & SW2 \\
\hline 11. & $\begin{array}{l}\text { spur width, measured } \\
\text { at a beginning part }\end{array}$ & SW3 \\
\hline 12. & lateral sepal length & LSL \\
\hline 13. & lateral sepal width & LSW \\
\hline 14. & ovary length & OL \\
\hline 15. & bract length & BL \\
\hline 16. & bract width & BW \\
\hline & & \\
\hline
\end{tabular}

\section{Results}

The morphological variability of the specimens examined was low (Tab. 2). The coefficients of variation (V) exceeded $20 \%$ in the following 4 characters only: leaf length and width, number of flowers, and inflorescence height (Tab. 2).

As shown by the Spearman correlation coefficients, direct correlations were observed between: 1) labellum length and width $(0.71) ; 2)$ labellum and ovary lengths $(0.69) ; 3)$ labellum and sepal lengths $(0.68) ; 4)$ labellum and spur lengths $(0.63) ; 5)$ bract length and width $(0.64) ; 6)$ spur width as measured in the central part and spur width as measured in the terminal part (0.73); 7) plant height and inflorescence length $(0.73)$; 8) plant height and the number of flowers $(0.63)$; and 9) inflorescence length and the number of flowers (0.74) (Tab. 3). 
Table 2. Variation of morphological characters in specimens of Platanthera chlorantha. Explanation of symbols: $1,2,3$, site number; $x$, arithmetic mean; min, max, minimum and maximum values, respectively; $V$, coefficient of variation. Character symbols as those in Table 1.

\begin{tabular}{|c|c|c|c|c|c|c|c|}
\hline & 1 & 2 & 3 & & 1 & 2 & 3 \\
\hline \multirow{5}{*}{ 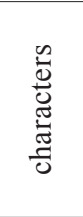 } & $\min -\max$ & $\min -\max$ & $\min -\max$ & \multirow{5}{*}{ 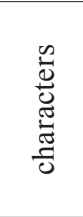 } & $\min -\max$ & $\min -\max$ & $\min -\max$ \\
\hline & $x[\mathrm{~mm}]$ & $x[\mathrm{~mm}]$ & $x[\mathrm{~mm}]$ & & $x[\mathrm{~mm}]$ & $x[\mathrm{~mm}]$ & $x[\mathrm{~mm}]$ \\
\hline & $V[\%]$ & $V[\%]$ & $V[\%]$ & & $V[\%]$ & $V[\%]$ & $V[\%]$ \\
\hline & \multicolumn{3}{|c|}{ totally $(1,2$ and 3$)$ : } & & \multicolumn{3}{|c|}{ totally (1, 2 and 3): } \\
\hline & \multicolumn{3}{|c|}{$x ; V$} & & \multicolumn{3}{|c|}{$x ; V$} \\
\hline \multirow[t]{4}{*}{ LL } & $10.0-19.8$ & $9.7-14.9$ & $9.9-18.25$ & OL & $10.0-19.8$ & $10.0-19.9$ & $12.8-26.1$ \\
\hline & 12.1 & 10.2 & 13.8 & & 15.2 & 12.2 & 17.8 \\
\hline & 14 & 9 & 15 & & 21 & 17 & 15 \\
\hline & \multicolumn{3}{|c|}{$12.2 ; 17$} & & \multicolumn{3}{|c|}{$15.2 ; 21$} \\
\hline \multirow[t]{4}{*}{ LW } & $1.9-4.6$ & $1.9-3.4$ & $1.7-3.65$ & $\mathrm{BL}$ & $10.05-19.8$ & $12.6-17.0$ & $8.4-24.7$ \\
\hline & 2.5 & 2.2 & 2.5 & & 15.1 & 14.9 & 15.5 \\
\hline & 21 & 13 & 17 & & 9 & 7 & 21 \\
\hline & \multicolumn{3}{|c|}{$2.5 ; 20$} & & \multicolumn{3}{|c|}{$15.1 ; 14$} \\
\hline \multirow[t]{4}{*}{ LSL } & $8.5-12.7$ & $8.2-12.1$ & $8.3-13.9$ & BW & $3.2-6.3$ & $3.1-4.8$ & $2.7-7.6$ \\
\hline & 9.8 & 9.2 & 10.6 & & 4.4 & 4.0 & 4.4 \\
\hline & 10 & 8 & 12 & & 17 & 11 & 21 \\
\hline & \multicolumn{3}{|c|}{$9.9 ; 12$} & & \multicolumn{3}{|c|}{$4.3 ; 18$} \\
\hline \multirow[t]{4}{*}{ LSW } & $2.7-6.8$ & $3.2-6.3$ & $2.9-5.7$ & $\mathrm{H}$ & $203.0-563.0$ & $202.0-470.0$ & $255.0-700.0$ \\
\hline & 4.6 & 4.6 & 4.2 & & 389.0 & 374.8 & 439.4 \\
\hline & 19 & 16 & 17 & & 18 & 16 & 19 \\
\hline & \multicolumn{3}{|c|}{$4.5 ; 18$} & & \multicolumn{3}{|c|}{$400.0 ; 18$} \\
\hline \multirow[t]{4}{*}{ SL } & $19.8-34.8$ & $19.8-29.9$ & $21.6-34.0$ & LFW & $19.0-65.0$ & $17.0-59.0$ & $23.0-82.0$ \\
\hline & 25.2 & 23.2 & 27.9 & & 36.2 & 39.3 & 52.3 \\
\hline & 14 & 9 & 10 & & 26 & 26 & 25 \\
\hline & \multicolumn{3}{|c|}{$25.5 ; 13$} & & \multicolumn{3}{|c|}{$41.8 ; 31$} \\
\hline \multirow[t]{4}{*}{ SW1 } & $1.05-2.3$ & $1.1-2.3$ & $0.85-1.8$ & LFL & $52.0-205.0$ & $51.0-195.0$ & $85.0-275.0$ \\
\hline & 1.45 & 1.5 & 1.3 & & 123.9 & 147.8 & 182.5 \\
\hline & 19 & 16 & 15 & & 24 & 21 & 22 \\
\hline & \multicolumn{3}{|c|}{$1.4 ; 19$} & & \multicolumn{3}{|c|}{$146.9 ; 28$} \\
\hline \multirow[t]{4}{*}{ SW2 } & $1.0-1.8$ & $1.0-1.6$ & $1.2-2.2$ & NF & $4-19$ & $7-21$ & $6-37$ \\
\hline & 1.3 & 1.3 & 1.6 & & 12 & 13 & 15 \\
\hline & 17 & 14 & 16 & & 26 & 25 & 33 \\
\hline & \multicolumn{3}{|c|}{$1.4 ; 18$} & & & $13 ; 31$ & \\
\hline SW3 & $0.85-2.0$ & $1.0-1.7$ & $1.1-2.2$ & IL & $49.0-214.0$ & $48.0-204.0$ & $55.0-255.0$ \\
\hline & 1.4 & 1.4 & 1.5 & & 121.4 & 136.3 & 132.0 \\
\hline & 16 & 14 & 16 & & 26 & 28 & 33 \\
\hline & & $1.4 ; 16$ & & & & $128.1 ; 31$ & \\
\hline
\end{tabular}


Table 3. Spearman's rank correlation coefficient matrix for specimens of $P$. chlorantha. In bold absolute values $\geq 0.60$. Character symbols as those in Table 1 .

\begin{tabular}{|l|c|c|c|c|c|c|c|c|c|c|c|c|c|c|c|}
\hline Characters & LL & LW & LSL & LSW & SL & SW1 & SW2 & SW3 & OL & BL & BW & H & LFW & LFL & NF \\
\hline IL & 0.08 & 0.12 & 0.13 & 0.15 & 0.11 & 0.14 & 0.20 & 0.25 & 0.09 & 0.27 & 0.25 & $\mathbf{0 . 7 3}$ & 0.49 & 0.44 & $\mathbf{0 . 7 4}$ \\
\hline NF & 0.16 & 0.11 & 0.19 & 0.04 & 0.16 & -0.05 & 0.22 & 0.18 & 0.20 & 0.16 & 0.11 & $\mathbf{0 . 6 3}$ & 0.57 & 0.54 & \\
\hline LFL & 0.21 & 0.07 & 0.25 & -0.04 & 0.32 & -0.19 & 0.33 & 0.16 & 0.28 & 0.15 & 0.15 & 0.53 & 0.57 & & \\
\hline LFW & 0.24 & 0.11 & 0.26 & 0.03 & 0.25 & -0.13 & 0.34 & 0.24 & 0.25 & 0.18 & 0.10 & 0.56 & & & \\
\hline H & 0.35 & 0.25 & 0.25 & 0.05 & 0.31 & -0.06 & 0.28 & 0.29 & 0.30 & 0.30 & 0.29 & & & & \\
\hline BW & 0.54 & 0.56 & 0.49 & 0.25 & 0.45 & 0.10 & 0.36 & 0.36 & 0.42 & $\mathbf{0 . 6 4}$ & & & & & \\
\hline BL & 0.44 & 0.41 & 0.44 & 0.23 & 0.27 & 0.21 & 0.17 & 0.28 & 0.27 & & & & & & \\
\hline OL & $\mathbf{0 . 6 9}$ & 0.48 & 0.55 & -0.04 & 0.57 & -0.22 & 0.37 & 0.28 & & & & & & & \\
\hline SW3 & 0.35 & 0.41 & 0.33 & 0.17 & 0.42 & 0.49 & $\mathbf{0 . 7 3}$ & & & & & & & & \\
\hline SW2 & 0.45 & 0.37 & 0.42 & 0.16 & 0.50 & 0.25 & & & & & & & & & \\
\hline SW1 & -0.14 & 0.11 & 0.02 & 0.33 & -0.14 & & & & & & & & & & \\
\hline SL & $\mathbf{0 . 6 3}$ & 0.41 & 0.51 & -0.01 & & & & & & & & & & & \\
\hline LSW & 0.04 & 0.12 & 0.32 & & & & & & & & & & & & \\
\hline LSL & $\mathbf{0 . 6 8}$ & 0.48 & & & & & & & & & & & & & \\
\hline LW & 0.71 & & & & & & & & & & & & & & \\
\hline
\end{tabular}

As shown by Kruskal-Wallis test, the between-sites differences in most morphological characters of $P$. chlorantha were significant ( $\mathrm{p} \leq 0.05$ ) (Tab. 4). The Dunn's multiple comparisons test applied showed specimens from sites 1 and 2 to differ significantly in 7 characters, 11 characters being significantly $(\mathrm{p} \leq 0.05)$ different between sites 1 and 3 , and 13 characters being significantly $(\mathrm{p} \leq 0.05)$ different between sites 2 and 3. The largest differences $(\mathrm{p} \leq 0.001$ and $p \leq 0.01)$ were found in lengths of the labellum, spur, ovary, and leaf (Tab. 4). The highest values of those characters were recorded in specimens growing in the Karnieszewice Forestry (site 3) (Fig. 1A-D).

Table 4. Results of Kruskal-Wallis test and the post hoc Dunn's multiple comparisons test, showing significance of differences in morphological characters of $P$. chlorantha specimens. Explanation of symbols: $1,2,3$, site number; $H, H$ test value; ns, non-significant; $p$, significance level; $* p \leq 0.05$; ** $p \leq 0.01 ; * * * p \leq 0.001$. Character symbols as those in Table 1 .

\begin{tabular}{|c|c|c|c|c|c|}
\hline \multirow{3}{*}{ Characters } & \multirow{2}{*}{\multicolumn{2}{|c|}{ Kruskal-Wallis test }} & \multicolumn{3}{|c|}{ Dunn's multiple comparisons test } \\
\hline & & & $1-2$ & $1-3$ & $2-3$ \\
\hline & $\mathrm{H}$ & $\mathrm{p}$ & $\mathrm{p}$ & $\mathrm{p}$ & $\mathrm{p}$ \\
\hline 1 & 2 & 3 & 4 & 5 & 6 \\
\hline LL & 82.232 & 0.0000 & $* * *$ & $* * *$ & $* * *$ \\
\hline LW & 24.632 & 0.0000 & $* * *$ & ns & $* * *$ \\
\hline LSL & 36.901 & 0.0000 & $* *$ & $* *$ & $* * *$ \\
\hline LSW & 9.688 & 0.0079 & ns & $*$ & $*$ \\
\hline SL & 47.160 & 0.0000 & $* *$ & $* * *$ & $* * *$ \\
\hline
\end{tabular}




\begin{tabular}{|l|c|c|c|c|c|}
\hline \multicolumn{1}{|c|}{1} & 2 & 3 & 4 & 5 & 6 \\
\hline SW1 & 28.000 & 0.0000 & $\mathrm{~ns}$ & $* * *$ & $* * *$ \\
\hline SW2 & 35.811 & 0.0000 & $\mathrm{~ns}$ & $* * *$ & $* * *$ \\
\hline SW3 & 7.074 & 0.0291 & $\mathrm{~ns}$ & $\mathrm{~ns}$ & $*$ \\
\hline OL & 59.770 & 0.0000 & $* * *$ & $* * *$ & $* * *$ \\
\hline BL & 1.524 & 0.4667 & $\mathrm{~ns}$ & $\mathrm{~ns}$ & $\mathrm{~ns}$ \\
\hline BW & 8.652 & 0.0132 & $*$ & $\mathrm{~ns}$ & $\mathrm{~ns}$ \\
\hline H & 17.407 & 0.0002 & $\mathrm{~ns}$ & $* *$ & $* * *$ \\
\hline LFL & 62.652 & 0.0000 & $* *$ & $* * *$ & $* *$ \\
\hline LFW & 47.798 & 0.0000 & $\mathrm{~ns}$ & $* * *$ & $* * *$ \\
\hline NF & 19.737 & 0.0001 & $\mathrm{~ns}$ & $* *$ & $*$ \\
\hline IL & 4.501 & 0.1054 & $\mathrm{~ns}$ & $\mathrm{~ns}$ & $\mathrm{~ns}$ \\
\hline
\end{tabular}
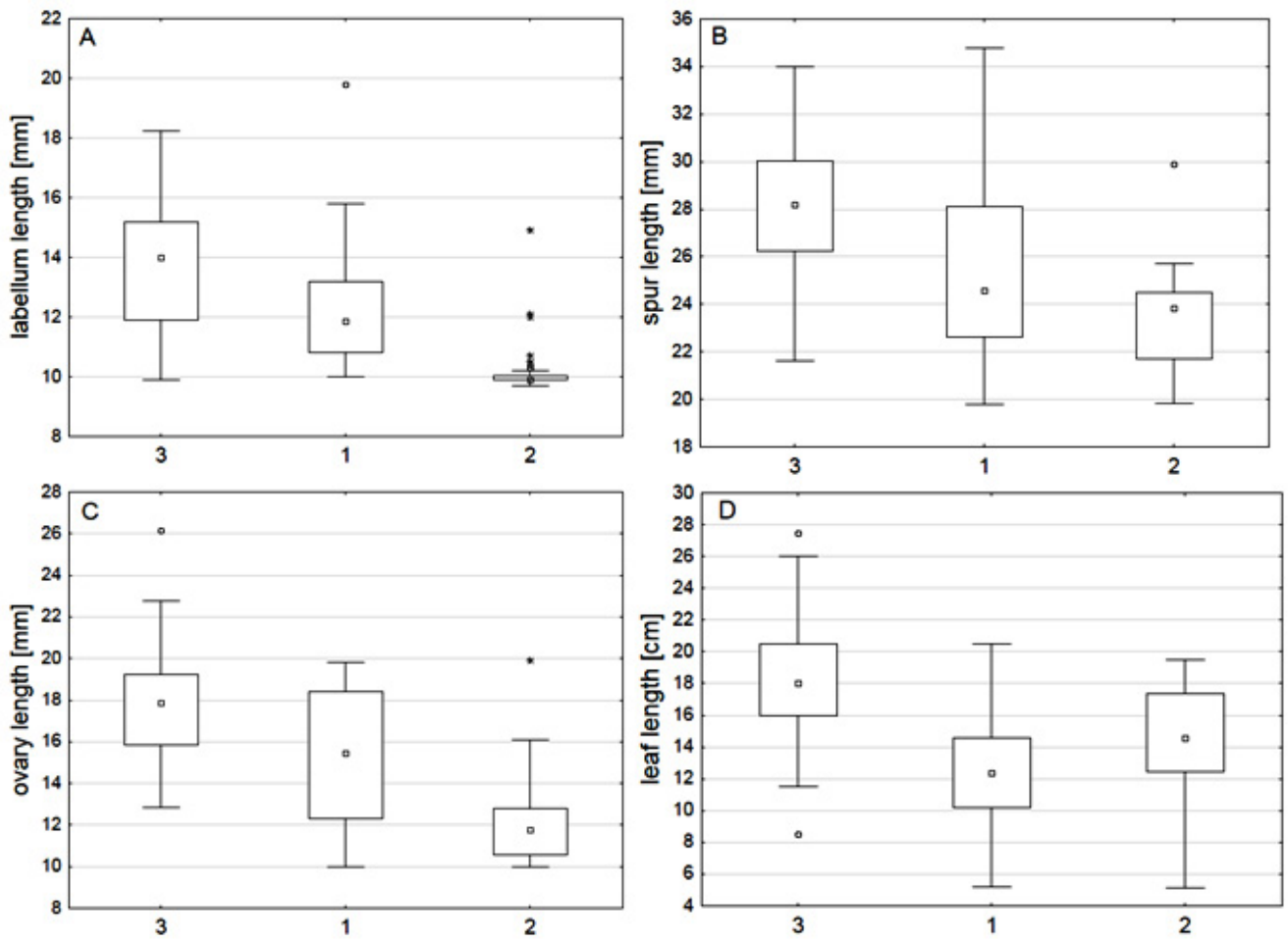

Figure 1. Ranges of dimensions of the four P. chlorantha characters in relation to collection site $(1,2,3)$. Large boxes indicate $25-75 \%$ of the interquartile ranges of values; small boxes represent median values; white circles and asterisks denote outliers and extreme values, respectively. 1 - site 1 (Dobrzany Forestry, forest section 589a); 2 - site 2 (Dobrzany Forestry, forest section 560g); 3 - site 3 (Karnieszewice Forestry) 
As shown by PCA, the first three principal components explained jointly $64 \%$ of the variation (39, 14 and 11\%) (Fig. 2). The highest factor loadings of the first component involved the following variables: labellum length and width $(-0.79$ and -0.60 , respectively), sepal length $(-0.77)$, spur length $(-0.63)$, spur widths as measured in the central and terminal part $(-0.69$ and -0.61 , respectively), ovary width $(-0.67)$, bract length and width ( -0.65 and -0.68 , respectively), plant height $(-0.72)$, leaf length and width $(-0.60$ and -0.65 , respectively), number of flowers $(-0.61)$ and inflorescence length $(-0.58)$. Three characters: number of flowers $(0.50)$, inflorescence length $(0.57)$ and leaf length $(0.59)$ produced high loadings on the second principal component, whereas the sepal width (0.51) and spur width at the base (0.81) showed high loadings on the third principal component.
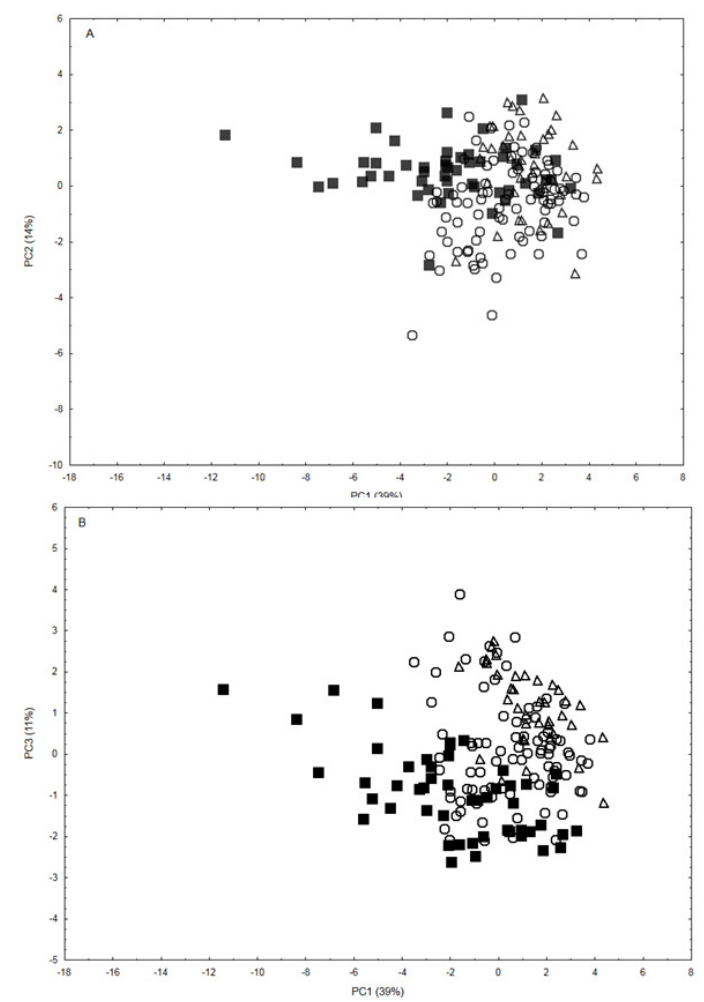

Figure 2. Results of the principal component analysis (PCA) for the 174 P. chlorantha specimens examined. A - distribution along the PC1 and PC2 axes; $\mathrm{B}$ - distribution along the PC1 and PC3 axes. Explanation of symbols: $\bigcirc$ - site 1 (Dobrzany Forestry, forest section 589a); $\triangle$ - site 2 (Dobrzany Forestry, forest section $560 \mathrm{~g}$ ); - site 3 (Karnieszewice Forestry)

The ordination space showed no clear groupings. However, most specimens from site 1 occupied the central position along the first PCA axis, the site 2 and 3 specimens tending towards aggregation at the right- and left-hand sides of the graph, respectively (Fig. 2A). Distribution of the specimens along the first PCA axis as well as the factor loadings associated with it allowed 
to conclude that most site 3 individuals were endowed with longer labella, sepals, spurs and ovaries as well as longer and wider leaves, compared to the specimens collected at sites 1 and 2 (Fig. 2). The lowest values of the characters analysed were typical of site 2 specimens (Tab. 2; Fig. 2).

\section{Discussion}

The genus Platanthera is characteristic in having a long spur and labellum, therefore dimensions of those components are being paid a particular attention in floras and monographs (e.g. Bateman, Sexton 2008). Table 5 lists examples of spur and labellum size ranges for different regions of Europe (Webb 1980; Komarov, Chernyakovskaya 1986; Stace 1997; Szlachetko 2001; Jeanmonod, Gamisans 2007; Lauber, Wagner 2007). Other authors mentioned only mean values of those variables; for example, Bateman and Rudall (2006) reported the mean length of spur and labellum (29 and $13.8 \mathrm{~mm}$, respectively); Stpiczyńska (2003) reported a mean of 31.5 for specimens collected in the vicinity of Lublin. The specimens from the sites in NW Poland, examined in this study, showed generally smaller spur and labellum, $25.5 \mathrm{~mm}$ ( $\max 34.8 \mathrm{~mm}$ ) and $12.2 \mathrm{~mm}(\max 19.8 \mathrm{~mm}$ ), respectively. Numerous authors reported the spur of $P$. chlorantha to widen somewhat in its terminal part; however, as shown by this study, there were no significant differences between the spur widths as measured in different places (cf. Tab. 2).

Table 5. Platanthera chlorantha labellum and spur length ranges in Europe.

\begin{tabular}{|l|c|c|}
\hline \multirow{2}{*}{\multicolumn{1}{|c|}{ Flora /monograph }} & Labellum length & Spur lenght \\
\cline { 2 - 3 } & $(\mathrm{mm})$ & $(\mathrm{mm})$ \\
\hline Komarov \& Chernyakovskaya (1986) & $11-14$ & $18-27$ \\
\hline Stace (1997) & $10-16$ & $19-28$ \\
\hline Webb (1980) & $8-12$ & $18-27$ \\
\hline Lauber \& Wagner (2007) & $8-20$ & $15-25$ \\
\hline Jeanmonod \& Gamisans (2007) & $9-18$ & $16-40$ \\
\hline Szlachetko (2001) & $11-18$ & up to 50 \\
\hline present study & $9.7-19.8$ & $19.8-34.8$ \\
\hline
\end{tabular}

As shown by the measurements taken, the labellum and spur size significantly differentiated between the $P$. chlorantha specimens from the three different sites (cf. Tab. 4). As reported by Bateman and Rudall (2006) and Bateman and Sexton (2008), lengths of the labellum and spur are affected by geographic location and habitat conditions such as soil $\mathrm{pH}$ and moisture content and the extent of shading. The most uniform conditions (shading and soil moisture content) in the area of study occurred at site 2 (the Dobrzany Forestry, section 560g), hence the relatively narrow range of variation in the character in question (coefficient of variation of $9 \%$ ). Some specimens at site 1 (Dobrzany, section 589a) and 3 (Karnieszewice) grew in sunny places whereas others were found at shaded spots, hence the higher variability of the spur and labellum dimensions (coefficient of variation for LL of 14 and $15 \%$ at site 1 and 3, respectively; the respective coefficients of variation for SL were 14 and 10\%). According to Bateman and Sexton (2008), the southern England's $P$. chlorantha specimens growing in shaded spots usually featured spurs 
longer than those found on specimens growing in open spaces; no significant correlation between the mean spur length and habitat conditions were revealed in northern England. The results reported in this study provide no clear-cut answers to the question if the specimens growing at shaded sites develop longer labella and spurs, but it cannot be denied that specimens affected by similar habitat conditions are less variable morphologically. In addition, dimensions of certain flower components are positively correlated with each other (notably the labellum length vs. length of the spur, ovary and sepals).

Acknowledgements. The authors wish to thank the staff of the Dobrzany and Karnieszewice Forestries for pointing out the P. chlorantha sites in their respective areas. Particular thanks are due to Mr W. W. Borzęcki, the forest ranger at Dobrzany, and Mr T. Kapustyński, the Deputy Forestry Head at Karnieszewice for their assistance in field work.

\section{References}

Bateman R.M., Rudall P.J. 2006. Evolutionary and Morphometric Implications of Morphological Variation Among Flowers Within an Inflorescence: A Case-Study Using European Orchids. Annals of Botany, 98: 975-993.

Bateman R.M., Sexton R. 2008. Is spur length of Platanthera species in the British Isles adaptively optimized or an evolutionary red herring? Watsonia, 27: 1-21.

Bateman R.M., Karen E., James K.E., Luo Y., Lauri R.K., Fulcher T., Cribb P.J., Chase M.W. 2009. Molecular phylogenetics and morphological reappraisal of the Platanthera clade (Orchidaceae: Orchidinae) prompts expansion of the generic limits of Galearis and Platanthera. Annals of Botany, 104: 431-445.

Claessens J., Kleynen J. 2006. Anmehungen zur Hybridbildung bei Platanthera bifolia und P. chlorantha. Journal Europäischer Orchideen, 38: 3-28.

Hultén E., Fries M. 1986. Atlas of North European vascular plants: north of the Tropic of Cancer. Königstein, Koeltz Scientific Books, p. 498.

Jeanmonod D., Gamisans J. 2007. (eds.). Flora Corsica. Édisud, p. 901.

Komarov V., Chernyakovskaya E. 1986. Flora of the U.S.S.R. (Flora SSSR). Volume 4: Liliiflorae and Microspermae. Bishen Singh Mahendra Pal Singh. Dehra Dun, India.

Lauber K., Wagner G. 2007. Flora Helvetica. Haupt Verlag, Bern-Stuttgard-Wien, p. 1631.

Matuszkiewicz W. 2006. Przewodnik do oznaczania zbiorowisk roślinnych Polski. In: Vademecum Geobotanicum 3. J.B. Faliński (ed.). Wyd. Nauk. PWN, Warszawa, p. 537.

Mirek Z., Piękoś-Mirkowa H., Zając A., Zając M. 2002. Flowering plants and pteridophytes of Poland a checklist. In: Biodiversity of Poland 1, Z. Mirek (ed.). W. Szafer Institute of Botany, Polish Academy of Sciences, Kraków, p. 442.

Nilsson L.A. 1983. Processes of isolation and introgressive interplay between Platanthera bifolia (L.) Rich. and P. chlorantha (Custer) Reichb. (Orchidaceae). Botanical Journal of the Linnean Society, 87: $325-350$.

Nilsson L.A. 1985. Characteristics and distribution of intermediates between Platanthera bifolia and $P$. chlorantha (Orchidaceae) in the Nordic countries. Nordic Journal of Botany, 5: 407-419.

Stace C.A. 1997. New Flora of the British Isles (2nd edn). Cambridge University Press, Cambridge, p. 1130.

Statsoft Inc. 2007. STATISTICA (data analysis software system), version 8.0. www. statsoft.com.

Stpiczyńska M. 2003. Floral longevity and nectar secretion of Platanthera chlorantha (Custer) Rchb. (Orchidaceae). Annals of Botany, 92: 191-197. 
Webb D.A. 1980. Platanthera L.C.M. Rich. In: Flora Europaea 5, T.G. Tutin, V.H. Heywood, N.A. Burges, D.M. Moore, D.H. Valentine, S.M. Walters, D.A. Webb (eds.). Cambridge University Press, Cambridge, pp. 331-332.

Zając A. 1978. Założenia metodyczne atlasu rozmieszczenia roślin naczyniowych w Polsce. Wiadomości Botaniczne, 22 (3): 145-155.

Zając A., Zając M. (eds.) 2001. Atlas rozmieszczenia roślin naczyniowych w Polsce. Pracownia Chorologii Komputerowej Instytutu Botaniki Uniwersytetu Jagiellońskiego, Kraków, p. 714.

Zarzycki K., Trzcińska-Tacik H., Różański W., Wołek J., Korzeniak U. 2002. Ecological indicator values of vascular plants of Poland. In: Biodiversity of Poland 2. Z. Mirek Z. (ed.). W. Szafer Institute of Botany, Polish Academy of Sciences, Kraków, p. 183.

Żukowski W. \& Jackowiak B. 1995. Lista roślin naczyniowych ginących i zagrożonych na Pomorzu Zachodnim i w Wielkopolsce. In: Ginace i zagrożone rośliny naczyniowe Pomorza Zachodniego i Wielkopolski. W. Żukowski, B. Jackowiak (eds.). Prace Zakł. Taks. Roślin UAM, Bogunki, Wyd. Nauk. Poznań, 3, pp. 9-96.

Cite as: Więcław H., Kurnicki B. 2016. Morphological variation of Platanthera chlorantha (Orchidaceae) in forest sites of NW Poland. Acta Biologica, 23: 139-149. DOI: 10.18276/ab.2016.23-12. 